\title{
Africa-China-Europe relations: Conditions and conditionalities
}

\author{
Adams Bodomo \\ Department of African Studies, University of Vienna \\ Austria \\ adams.bodomo@univie.ac.at
}

Abstract. This paper uses two concepts, conditions and conditionalities, to explain the differing approaches between China and the European Union (EU) in regards to how these two entities engaged African countries sociopolitically, socio-economically, and socio-culturally between 2000 and 2018 . Using mixed methods (both qualitative and quantitative) to obtain data we argue that the EU tends to impose more conditionalities on African countries than China does, and in so doing China is making more investment progress in Africa than Europe does. As part of the practical results of this research

Received:

March, 2019

1st Revision:

May, 2019

Accepted:

November, 2019

DOI:

$10.14254 / 2071$

$8330.2019 / 12-4 / 8$ the paper outlines a number of ways the EU can re-engage Africa to match up or even surpass Chinese engagement on the continent of Africa, including less political conditionalities, more trade than development aid, and also inclusion of African diaspora more in Europe's dealings with African countries.

Keywords: Chinese investment, trade, European development aid, infrastructure, Africa.

JEL Classification: P45, P51, O55

\section{INTRODUCTION}

On September 3, 2018, President Xi Jinping of the People's Republic of China in a speech at the Forum for Africa China Cooperation (FOCAC) conference in Beijing, spelt out five ways in which the Chinese relate to Africa without interfering in Africa's internal affairs - what has now come to be known as the "five-nos" approach":

China values sincerity, friendship and equality in pursuing cooperation. The over 1.3 billion Chinese people have been with the over 1.2 billion African people in pursuing a shared future. We respect Africa, love Africa and support Africa. We follow a "five-no" approach in our relations with Africa: no interference in African 
countries' pursuit of development paths that fit their national conditions; no interference in African countries' internal affairs; no imposition of our will on African countries; no attachment of political strings to assistance to Africa; and no seeking of selfish political gains in investment and financing cooperation with Africa. We hope this "five-no" approach could apply to other countries as they deal with matters regarding Africa. For China, we are always Africa's good friend, good partner and good brother. No one could undermine the great unity between the Chinese people and the African people. - Xi Jinping, Keynote Speech at FOCAC 2018 in Beijing, China

These five-no principles have now come to be known as one of the clearest statements of Beijing's claim to dealing with Africa without making asymmetrical demands on their African partners. Below we would like to discuss the notions of conditions and conditionalities with this new statement with a view to answer questions such as what are the differences between Chinese and European business engagements in Africa, why is China investing and trading far more than many European countries in Africa, and how can Europe re-engage Africa in a more improved way?

Conditions of engagement are different from conditionalities of engagement. Every engagement between entities such as nations and companies and individuals has a basic set of rules or tenets to be met by both parties. These are conditions of engagements. They are agreements between more or less equal and willing partners for the purpose of achieving what might be called win-win engagements. Conditions are therefore symmetric contractual agreements. A bargained, negotiated, and mutually-agreed interest rate in a loan contract between a European or Chinese government entity and an African country or company is a condition for loan transaction.

Conditionalities, on the other hand, are more or less asymmetrical, arm-twisting requirements that one of the parties in a relationship demands from other parties. Conditionalities are asymmetric, extracontractual agreements. A demand by a European country to an African country to change its internal political system before an investment transaction takes place is a conditionality. Structural Adjustment Programmes (SAPs) of the 1980s and beyond are typical conditionalities imposed by European- or general Western-dominated financial institutions on African countries.

In this paper we argue that in regards to the relations between Africa and Europe on the one hand and the relations between Africa and China on the other, Europe tends to impose more conditionalities in its dealings with Africa than is the case with China and its relations with Africa. In other words, while conditions of engagements requiring each party to show responsibility and fulfil its part of the agreement exist in relations between Africa and China and between Africa and Europe, Europe often resorts to imposing conditionalities in Africa-Europe engagements.

\section{LITERATURE REVIEW: AFRICA-CHINA-EUROPE RELATIONS}

Africa - China relations, especially China's $21^{\text {st }}$ Century intensified foray into Africa, are marked and defined to the international world, not so much by the two parties but by more than two decades of critical European and general Western reactions to China's activities in Africa (Bodomo 2009, 2010, 2015, 2016, 2017, 2018, 2019; Li 2016; Wissenbach 2008, 2009; Berger and Wissenbach 2007 etc), and hardly does any western media comment on Africa - China relations end without raising the issue of China's negative activities in Africa. I claim that Africa-China relations are thus defined and determined not just by Africa and China but also by European and general Western reactions to the contacts between Africa and China, and much of this reaction can be found in western media. Hence, I use the term Africa - China Europe relations to encode this triangular relationship. 
This Africa - China - Europe relationship is defined by a surprisingly robust anti-China agenda in Africa. While it is true that Europe and the West as a whole have policies claiming to promote trilateralism between Africa, China and Europe in Africa, the reaction is largely a negative campaign against the Chinese presence in Africa.

As I mention in Bodomo (2017), after one decade or more of criticism, as if to mimic the phrase, "if you cannot beat them, join them", the West has turned volt face, and proposed to "collaborate" with China in its African foray (Commission of European Communities 2008, Berger and Wissenbach 2007, Wissenbach 2008, etc). Even the European Commission now has a blue print for a so-called EU-ChinaAfrica trilateral dialogue and cooperation (Commission of the European Communities 2008).

This trilaterialism however pales in comparison to the West's anti-China agenda in Africa. To westerners and some Africans, China's Africa foreign policy often appears as a new form of economic imperialism (e.g. Games 2005), as a pure capitalist investment (e.g. Hilsum 2006) or as a neo-colonial venture (e.g. Jack Straw's speech in 2006 and Lamido Sanusi 2013).

China of course also criticizes Europe's engagement in Africa, albeit in a rather subtle manner. When President Xi outlined his five-nos approach, he ended by saying that he hopes others who deal with Africa would also abide by these five nos. He was obviously referring to decades of European conditionality and outright interference in the governing structures of African countries.

\section{METHODOLOGY}

In terms of research methodology, I adduced evidence for the positions arrived at in the paper by looking at the main features of European and Chinese engagements with Africa. As a methodological framework, I relied on qualitative and quantitative procedures of sifting through data and several pieces of evidence over a period of six years from journals, books, newspapers, and policy briefings and declarations from Forum for Africa - China Cooperation (FOCAC) and the European Union policy on Africa. I also use purely logical argumentations to defend my hypothesis that Europe tends to impose more conditionalities in its dealings with Africa than is the case with China and its relations with Africa. I show that Chinese propensity to impose less conditionalities on its African counterparts has led to more growth and expansion of China in Africa while the European engagement coloured by conditionalities has not fared as well as the Chinese engagement. I propose what must be done by European actors in order to chart a renewed partnership in Africa based on more symmetrical, equal relations than has been the case right from the colonial era until now.

\section{EMPIRICAL RESULTS AND DISCUSSION}

\subsection{Europe in Africa}

Some of the most fundamental questions that must be raised when we come to the question of European engagements with African over the years are why after so many decades of foreign direct investment (FDI) in Africa by the West (mainly Europe and the USA), Africa still remains one of the poorest and least industrialized parts of the globe? Did the West and Europe, in particular, contribute in the development of Africa or did it indeed under-develop Africa (Rodney 1972)? How can Europe (and the West as a whole) reposition itself in the wake of new and renewed investment players in the African investment stratosphere?

Following the Berlin conference of 1884 - 85 marking the beginning of what is often known as the Scramble for Africa (i.e. the beginning of European colonialism in Africa), much of Africa was formally 
carved out and colonized by three main European powers, including the United Kingdom, France, and Portugal, with others including Germany and Belgium. So any historical overview would dwell mainly on these major former colonial powers, though other Western European countries like Belgium, Germany, Spain, Denmark, Sweden, Finland, Norway, the Netherlands, Switzerland, Austria, and Italy also have made important contributions to investment in Africa. During this colonial period one could hardly talk of FDI as these African entities were considered integral parts of the European economies. A country like France even considered its colonies to be "Overseas Departments" (Departments d'Outre Mer) within the French civil service administrative hierarchy, so it would be highly problematic or even inconceivable to spell out the notion of foreign direct investment in such a situation.

Since the second half of the $20^{\text {th }}$ Century when most African countries began to get their independence from Europe and started charting their own political economies, FDI has steadily flowed in from Europe into Africa (and other developing countries). It is estimated that FDI in the 1970's flowed from the developed world (mostly the West, including Europe) to the developing countries (including Africa) at an average yearly rate of USD10 billion in the 1970's, USD20 billion in the 1980's, USD27 billion in the 1990's and up to USD210 billion at the turn of the Millennium. (Graham \& Spaulding, 2011).

In 2010, France had the largest FDI contributions compared to its European peers, given that France has a very large number of former colonies in Africa. The 2010 UNCTAD Trade Investment report says: "Most of the FDI flows to Africa come from only a small number of (...) countries..., led by the United States, France and the United Kingdom. During the period 1996-2000, the US alone accounted for more than $37 \%$ of total flows from developed countries, France for $18 \%$ and the UK for $13 \%$; Germany and Portugal followed at some distance." (UNCTAD World Investment Report 2010). By 2015, the UK had overtaken France as the largest European investor with 58 billion dollars to France's 54 billion dollars. (UNTAD World Investment Report 2017)

However substantial this French FDI is, the most important fact is that it has been falling rapidly. For instance, while French FDI accounted for 18\% as Smith (2010) says, "France's foreign direct investment in Africa has also plummeted since the Berlin Wall crumbled. While the African share stood at just over 30\% in 1989, it has been consistently below 5\% since the turn of the century."

The United Kingdom (UK), the next country with the largest number of former colonies on the African continent, also has substantial FDI outflows to Africa, indeed currently the highest, though its African FDI outflow is only a tiny fraction of its total FDI outflows. Figures show that of nearly BPD320 billion of FDI invested by UK companies between 2000 and 2004 only about 15 billion (or approximately 4.5\%) of that went to Africa, mostly to South Africa (UK Government National Statistics, Dec 13, 2005). It is not clear how this scenario of dwindling rate of UK investment in Africa, now that Britain has begun negotiations to leave the European Union following a referendum on June 23, 2016, dubbed the Brexit referendum.

To illustrate a 20-year historical overview of FDI from Europe, we provide a table of statistics, table 1, below showing FDI figures from major European countries (most of which are European Union member countries) to Africa between 1981 and 2000. 
Africa: accumulated FDI outflows from Western European countries 1981-1985, 1986-1990, 1991-1995 and 1996-2000 (Millions of dollars)

\begin{tabular}{|l|c|c|c|c|}
\hline \multicolumn{1}{|c|}{ Country } & $\mathbf{1 9 8 1 - 1 9 8 5}$ & $\mathbf{1 9 8 6 - 1 9 9 0}$ & $\mathbf{1 9 9 1 - 1 9 9 5}$ & $\mathbf{1 9 9 6 - 2 0 0 0}$ \\
\hline Austria & 72 & 33 & 7 & 221 \\
\hline Belgium & 99 & 40 & -47 & 242 \\
\hline Denmark & 19 & 24 & 1 & 340 \\
\hline Finland & - & 38 & 2066 & 4362 \\
\hline France & 1239 & 1001 & 402 & 2475 \\
\hline Germany & 504 & 332 & 213 & 678 \\
\hline Italy & 455 & 217 & 297 & -148 \\
\hline Netherlands & 94 & 153 & 145 & 1560 \\
\hline Norway & 99 & 12 & 96 & 576 \\
\hline Portugal & - & - & 50 & 197 \\
\hline Spain & - & - & 4 & 69 \\
\hline Sweden & 177 & 48 & 452 & 3269 \\
\hline Switzerland & -6 & 73 & 2376 & \\
\hline United Kingdom & 882 & 2193 & & \\
\hline
\end{tabular}

Source: UNCTAD, World Investment Report 2002.

From this table, we may say that historically the top 10 European investors in Africa over a long period of time have been France, the United Kingdom, Germany, Portugal, Netherlands, Italy, Spain, Denmark, Belgium, and Austria, each of which has 200 million dollars or more of investments by either governments or private companies from these countries. This order may have changed over the years; for instance, the UK has slightly overtaken France in the 2017 UNCTAD figures mentioned earlier.

So why has Africa not developed much despite this substantial FDI inflows from Europe? We may look at the essential features of European investment, in part, for answers to why after so much FDI outflow to Africa, the continent still remains what it is today, largely underdeveloped.

\subsection{Essential features and constraints of European investment in Africa}

One would have expected that Africa would have made some substantial headway in economic development, given this injection of FDI since the 1960s until now from Europe. Yet, one can claim, arguably, that many countries in Africa are even worse off than they were at independence in terms of the economic well-being of their people. I want to argue here that, putting internal political factors aside, FDI and the general European engagement did not do any substantial good in Africa because of three essential features of European investment.

\section{i. European socio-economic conditionalities}

European FDI and economic development assistance as a whole have always come to Africa on the back of many strings of socio-economic conditionalities. This is particularly the case with former colonial governments and financial institutions controlled by these governments. Many of these former European colonial powers, particularly France and the UK have always had the tendency to see FDI and the granting of loans to Africa as an economic tool to continue to have massive influence in running the economies they left behind. The most prominent of all socio-economic conditionalities are the demands by these European donors that African economies must privatize their government controlled corporations and follow such other structural adjustment programmes (SAPs) like trade liberalization and 
currency devaluation. Any people growing up in Africa, like the author, in the 1970s and 1980s would remember the socio-economic turmoil that SAPs imposed by Western-controlled economic institutions like the International Monetary Fund (IMF) and the World Bank visited on African countries like Ghana, Nigeria, Senegal, Kenya, and Zambia. SAPs on the whole demand countries to remove price controls on goods, remove government subsidies, lay off workers in over-bloated civil service structures and in corporations, devalue local currencies against the US dollar to make exports from such countries cheap for European importers, and so on. All these have the effects of cutting expenditure on education and social services to the extent that students and workers agitate through strikes and other aspects of civil disobedience. While some scholars may argue that SAPs are related more to aid than to FDI, the point here is to show that SAPs are imperfect attempts to mitigate the negative effects of investments. SAPs and other socio-economic conditionalities ultimately lead to generally unstable political systems and dismal economic welfare for the people, and thus to a large exodus of citizens away from these countries in search of better conditions of life in Europe and other Western countries. I believe that a large number of the professionals of African descent living in Europe (and the West as a whole) are economic refugees who had to flee the economic hardships meted out on African countries by European- (and American-) controlled SAPs. Immigration often involves push and pull factors (the push factors explain the reasons why people migrate away while the pull factors explain why they choose a particular destination to migrate to, if the migration is voluntary). Unstable economies that result from such socio-economic and sociopolitical conditionalities in the form of SAPs are an important push factor for migration away from Africa.

ii. The export of global socio-political values

In addition to the socio-economic conditionalities imposed by European investors in Africa, there are also socio-political conditionalities. In the context of this paper, socio-political conditionalities are constraints and rules imposed on African countries by European countries before any investment and other economic transactions occur between donor and recipient entities. These are different from the purely socio-economic conditionalities characterised by SAPs. These are attempts to directly influence the internal political structure of the country involved. They include the demand that countries must redesign their political system to be one of multi-party democracy, and that there must be a rule of law, free press, freedom of speech, etc. All these are seen as global socio-political views that the West, especially Europe and the US, attempts to impose on Africa and other developing polities. These conditionalities - multiparty democracy, rule of law, free press and freedom of speech - are often referred to as European values, especially for western European polities. While not denying the inherent good in them for promoting human rights and societal well-being, mainstream anti-imperialist activists often consider them as modernday post-colonial attempts to re-engineer colonial era "civilizing" missions - the need to bring civilization to "primitive" and less advanced societies.

\section{iii. European views of Africa as a bumanitarian burden}

A third group of features and constraints of European investment are socio-cultural in nature. They often take on a more humanitarian dimension and the perceived need to do good to humanity, which on the surface is a very good cultural value on the part of Europeans, but deeper down could be conceived as paternalistic in nature. One of the most distinctive aspects of European investment and general engagement with Africa from any other entity is the conceptualization of Africa as an economic burden, given its dismal colonial past in Africa that has left most countries with hardly any functional political economies. The consequences of seeing Africa in this way is that Europe has focused more on giving Africa "development aid" and less on purely engaging in trade and investment, something that makes it very different from other new investors like China.

Given these three types of investment features and constraints that have left Africa still worse off than it was before European intervention, some scholarly works (e.g. Rodney 1972) have tended to claim 
that Europe, indeed, through development "aid" and investment has actually exploited the resources of Africa to develop itself, rather than Africa. Europe therefore seems to have benefited more than Africa in Africa - Europe investment relations over the centuries. If this is the case, can Europe turn a new leaf in its investment relations with Africa in the $21^{\text {st }}$ Century? We will explore this in Section 4.6.

\subsection{China in Africa}

Chinese presence in Africa stretches back to the $15^{\text {th }}$ Century when Admiral Zheng He sailed to the East African Coast on a trading mission, opening the continent to trade exchanges with the Far East. Significant cooperation between Africa and China continued in the larger context of Africa - Asia relations during the 1955 Bandung Conference, which brought together for the first time most independent African and Asian countries resisting the pressure to be drawn into the Cold War. Many of these countries subsequently joined the "Nonaligned Movement", an alliance against colonialism, neocolonialism and imperialism, which refused allying with any of the two military blocks and focused instead on cooperation in economic development.

China, in the meantime, became a secondary and yet active Cold War player, in an era characterized by superpower skirmishes for ideological and economic influence in the developing world. In the 1960s Maoist China became particularly active in Africa through foreign assistance programmes supporting socialist leaders, which paid for flagship programmes such as the prominent Tazara railway, linking the port of Dar es Salam in Tanzania to inland Zambia (Monson 2009). Because of its Cold War era economic cooperation activities in Africa, China achieved a lot of political capital and a large amount of trust from many African leaders, which subsequently resulted in crucial support to Beijing, particularly within the aegis of the United Nations (UN), including during China's 1971 bid to a permanent representation within the UN Security Council (UNSC).

China's Cold War era presence in Africa was nonetheless very limited when compared to the intensified cooperation of the 1990s, which further increased since the turn of the Millennium. In 2000 China created the Forum for China - Africa Cooperation (FOCAC), a most significant event in the development of country-to-region political and economic relations. ${ }^{2}$ This model of regional cooperation has overshadowed political and economic fora that had long existed before between Africa and its former colonial masters, such as the Franco-African summits and the Commonwealth group meetings with the United Kingdom, and has subsequently been emulated by new investment competitors from the global South, including India (Broadman 2008, Chand 2011) and Turkey (Amra, 2001, Vicky 2011).

The launch of FOCAC inaugurated a new cooperation strategy and was symptomatic of a major overhaul of Africa - China relations in the making. In those same years, China's intensified quest for oil and raw materials brought Beijing to multiply its embassies in Africa, to open dozens of Confucius Institutes and to increase the number of government-sponsored programmes, including vocational training and scholarships offered to African nationals. ${ }^{3}$ While this campaign has often been portrayed by the West as continuing the same old quest for raw materials as the European colonizers did, I argue that there are fundamental strategic differences in this reinvigorated Africa - China relation. I develop this

\footnotetext{
${ }^{2}$ FOCAC is a triennial gathering of African and Chinese leaders alternating between African capitals and Beijing at which various development cooperation agendas are outlined and assessed. So far there have been six meetings: FOCAC 2000 in Beijing (Ministerial); FOCAC 2003 in Addis Ababa (Ministerial); FOCAC 2006 in Beijing (Summit); FOCAC 2009 in Sharm El Sheik (Ministerial); FOCAC 2012 in Beijing (Ministerial); FOCAC 2015 in Johannesburg (Summit).

${ }^{3}$ China has today the largest diplomatic network in Africa.
} 
argument by outlining some of the features that allow distinguishing Chinese economic engagement in Africa from European and other competitors' engagements, before giving a brief exposure of what lessons these competitors can learn from China's success and what we should conclude on the colonialist/neocolonialist charge.

\subsection{The Nature of today's Chinese engagement in Africa}

Historically, there is much truth to the claim that China's $21^{\text {st }}$ Century foray into Africa was mainly driven by its need for commodities, which were and continue to be essential to its large manufacturing economy. Trade between Africa and China began growing exponentially in the early 2000s, when China's import of primary products accounted for over $90 \%$ of total African imports (data between 2004 and 2011), with oil and fuel accounting for the lion's share (64\% of the total China-Africa trade in 2009), followed by iron ore and metals (24\%) and other bulk commodities, food and other agricultural products (5\%) (Raudino 2016).

In the early 2000s China also found in Africa profitable market access opportunities for its manufactured goods: a World Bank publication suggests that in 2004 as much as $87 \%$ of all Chinese exports to Africa were machinery and equipment, textile, apparel and other manufactured products (Raudino 2016). Chinese exports to Africa have also traditionally been more diversified than Chinese imports from Africa: using the Herfindahl-Hirschman index, Broadman (Broadman et al 2007) found that Africa's exports to China are highly concentrated in a few oil- and mineral-producing states, while the same index suggested a considerably greater diversity among the main African importers of Chinese manufactured goods.

Notwithstanding the above, there are a number of reasons why the relation between Africa and China cannot simply be defined in purely commercial terms. From an historical perspective, China has engaged Africa long before its economic boom of the 1990s, having promoted anti-colonial solidarity since the 1950s and having subsequently sustained many newly independent African countries in their quest for international legitimacy and recognition. China has traditionally been a staunch supporter of non-interference and avoided any direct meddling in African elections, civilian conflicts or regional wars, while nonetheless remaining an active contributor towards UN peacekeeping operations in Africa-to the point that it has today become the largest contributor of blue helmets among UNSC P5 members. Since 1949, China and Africa have reciprocally sustained their value systems in international fora, consistently advancing a developmental model that privileges "universal" economic rights over "Western-centered" human rights. Because of this, it would be reductive, simplistic and unfair to categorize China's engagement in Africa as purely driven by its need for resources.

What is most important, Chinese economic involvement in Africa has also evolved considerably in these last twenty years, to the point that what already represented a relative novelty in the early 2000s, can today be seen as a truly revolutionary venture. This is particularly noticeable with respect to: i) focus on economic relations rather than development assistance; ii) nature of investments and efficacy of implementation; iii) conditions of engagement and; iv) discourse on equality of partnership. These features put Chinese investments partially in contrast with Western development programmes in Africa, so there necessarily has to be a comparison.

i. Focus on economic relations rather than development assistance

A key feature of Chinese engagement in Africa is a relatively high ratio of Foreign Direct Investments (FDI) to Official Development Assistance (ODA) and trade to ODA when compared to the West. While ODA volumes to Africa have continued surging since decolonization, in the early 2000s China has taken a different path by channeling increasing resources to FDI and trade creation. The centrality of i) a positive 
Trade Balance (particularly via integration in global value chains and exports to hard currency markets) and ii) Foreign Direct Investments (particularly via technology transfer in sectors with high value-adding potential) as key drivers of growth had been discussed for a long time in international development circles -4 yet, this key point remained almost unheard of among western countries for an equally long time, and this despite the fact that a growing number of African and international economists had consistently been pointing at it. ${ }^{5}$ As a result, while the West remained focused on traditional (grants and technical assistance) and innovative (blending financing instruments) ODA paradigms of development despite a theoretical focus around the "trade not aid" cooperation model, China was truly capitalizing on it, both in its policies and rhetoric.

African FDI inwards flows fluctuate widely from year to year and data from different sources are often discrepant-yet, there is emerging evidence that China is turning into the single most important provider of Greenfield and Brownfield investments to Africa. In 2016 China was the largest investor in Africa by FDI flow value and the third-largest by number of new FDI projects. ${ }^{6}$ Looking at FDI stock, all metrics suggest that China is quickly approaching the US and other European leading investors; according to UNCTAD, in 2016 China had the fourth largest stock of investments (USD 35 Billion) after the US (USD 64 Billion), UK (USD 58 Billion) and France (USD 54), and before South Africa and Italy (USD 22 each) and India (USD 17 Billion). What remains most impressive is the pace at which Chinese FDI stock in Africa is growing: $+170 \%$ between 2010 and 2015 , while for traditional investment partners this figure either remained in the low two digits (US 16\% and UK 23\%) or moved altogether into negative territory (France -3.8\%) due to the consequences of the 2008 financial crisis (UNCTAD 2017).

Trade-wise, there is no doubt that China has become the most important bilateral trading partner for the African continent—-bilateral trade accounted for USD 120 Billion in 2016 against USD 33 Billion for the US and USD 166 for the whole of Europe and Central Asia. ${ }^{7}$ While both the West and China have a heavily skewed trade balance structure with Africa-with overly positive Current Accounts in all African countries with the exception of few commodity exporters-China has nonetheless been growing in proportional weight. As Chinese investments diversify, so does its trade structure with Africa.

\section{ii. Nature of investments and efficacy of implementation}

Contrary to much of the western rhetoric on Chinese investments in Africa, these have gone beyond resource extraction for a long time now: Sautman and Yan (2007) already noticed in the mid-2000s that, while roughly $75 \%$ of American FDI to Africa was concentrated in the oil sector, reported figures on Chinese FDI to Africa between 1979 and 2000 suggested that $64 \%$ of investments went into manufacturing and $28 \%$ to natural resources. Today, in an average year, Chinese investments in construction are roughly at the same level of investments in mining, while manufacturing comes third. In absolute terms this translates into China having become the largest foreign investor in African infrastructures. Increasing investment and trade diversification in the last years also show from China's

\footnotetext{
${ }^{4}$ At Government level, former South African President Thabo Mbeki was among the first to raise the issue of foreign direct investments during the Tokyo International Conference on African Development (TICAD) in 1998.

${ }^{5}$ See in particular the work of Moyo $(2009,2010)$.

${ }^{6}$ According to UNCTAD 2017 World Investment Reports, in 2016 China invested USD 36 Billion in greenfield projects in Africa, followed by United Arab Emirates (USD 11 Billion); Morocco (USD 4.7 Billion); Saudi Arabia and Italy (USD 4 Billion each). In that year China also had one of the strongest brownfield activities (cross-border M\&A) in the continent.

${ }^{7}$ Data retrieved from World Bank's Database "World Integrated Trade Solutions". Available at: https://wits.worldbank.org/ (last accessed: 15 March 2018).
} 
new partners in Africa: recently, Chinese investments have increasingly concentrated both in resourcescarce countries-including Ethiopia, which has few resources to offer but a 100 million people-strong market—and mature and diversified economies, including Egypt and South Africa. ${ }^{8}$ These recent patterns are soothing criticisms from those who saw a skewed distribution of investments during the early Chinese moves in Africa, mostly focused in resource-rich and industrial-poor countries

Being a centralized and authoritarian polity, China enjoys an indisputable advantage in the implementation of its projects. Because of its own lack of western-style electoral democracy and civil society participation to political life, Chinese authorities have been able to steer an incredibly ambitious administrative and economic reform agenda with an unprecedented level of effectiveness. As much human rights-based criticism as this might have attracted in the West, China managed the most stunning feat in the history of public development policies: lifting some 500 million people—roughly half of its population—out of poverty in the space of three decades: $1981-2012 .{ }^{9}$ This could only be achieved because of Beijing's interventionist and centralized governance model: none of the most successful western-style electoral democracies could come close to the breakneck growth rates achieved by China.

Beijing has succeeded in translating this governance and management modality in its relation with Africa, setting up investment programs more speedily and efficiently than most of its western competitors.

iii. Conditions of engagement

There has been much myth-making around the contention that Chinese investments in Africa are unconditional and without asking questions. The reality, however, is that China negotiates conditions of engagement, which are both economic and diplomatic. Most overseas Chinese investments are carried out via State-Owned Enterprises, which come with a heavy set of economic ties, including on the sourcing of all production factors: capital, machineries and labor used in Chinese investments are mostly coming from China. Equally, there are a number of political conditions asked to African Governments, the most important being allegiance within International Organizations with respect to voting behavior, and the "One China policy" condition, e.g. the request to oppose the recognition of Taiwan as the sovereign and independent Republic of China. The impact of Beijing's sustained diplomatic campaign in Africa has become obvious in the 1990s and 2000s: Taiwan has lost official recognition from a number of African countries and today maintains official diplomatic relations with only one country Swaziland/Eswatini.

While the sum of Western FDI stocks remains very large in Africa and while many African countries are continuing to accept fresh, heavily conditioned Western investments, these facts do not gainsay the fact that Western conditionalities have often backfired, and that the Chinese no-political-questions-asked engagement modality has proved more successful altogether. When given an opportunity in the early 2000s, most African governments have been delighted at dropping western contractors to embrace Chinese loans and investment offers. To this extent, it is difficult to understate the importance that decades of accumulated African resentment at externally-imposed and often arbitrary conditionalities played upon African leaders' decision on taking a new business course. Notorious cases include Angolan oil fields in the early 2000s. The departure of the long-time leader, Robert Mugabe, will prove a testing case in verifying the future market position of China in the post-Mugabe environment: arguably, after almost 15 years of sour relations, the UK and other western countries are now ill-positioned to gain back their influence and economic leverage in the country.

\footnotetext{
${ }^{8}$ A review of total Chinese FDI flows stretching back to 2003 reveals that by 2017 Egypt had become the first recipient country; South Africa the 4th; Ethiopia the 6th and Morocco the 10th. Source: fDi market.

${ }^{9}$ World Bank in China
} 


\section{iv.Discourse on the equality of partnership}

Beijing brings to Africa a particularly attractive and rather refreshing approach with regards to the discourse around its political and economic relations-called here a new language of engagement. China comes to Africa with words and phrases in its lexicon bag like "brother", "comrades in arms against neocolonialism", "people of the developing world comparing notes", "win-win partnerships" and similar, all centering around the theme of South-South cooperation.

African leaders are not naïve people. Yet, given decades of neo-colonial discourse involving former European colonial masters handing down conditionalities on its former African subjects, this approach from the Chinese Government has proved rather refreshing to anti-imperialist movements in Africa, being indeed music in the ears of many African leaders tired of being dictated to by Western Ministries, development agencies and International Financial Institutions.

At least in its public statements, China refrains from being judgmental about the internal political machinations of African countries, as opposed to the West's socio-political conditionalities vented on proudly open information platforms. These requests often include regime change and formal democratization before large humanitarian and development programmes can be mobilized in countries with anti-West leadership and desperate economic and humanitarian conditions, including Zimbabwe and Sudan in the recent past. Such conditional requests create differences with the many cases in which western countries have done business and extended development assistance to pro-West African dictators-from Hosni Mubarak of Egypt and Omar Bongo of Gabon in the very recent past, to Paul Biya of Cameroon, Teodoro Obiang of Equatorial Guinea and Denis Sassou of the Republic of the Congo in the present. The use of such blatant double standards has not gone unnoticed in the African civil society, which appreciates the Chinese ability to separate politics from investments and ideology from the moral imperative of meeting African people's basic needs.

\subsection{China's success in Africa: Lessons for other investors}

Arguably, the most important lesson international investors can learn from Chinese ventures in Africa is risk taking. Prior to the era of globalization of investments, Africa was faced with what many referred to as the marginalization of Africa. The end of the Cold War in the 1990s was read by some to mean that Africa would no longer be a geopolitically-relevant region, and much less economically so. However, China read otherwise and while others appeared to be relaxing, it entered Africa in full force, also venturing into war-torn and rather unstable political economies. The result was that it paid off handsomely. Cases in point are Angola, Sudan and Zimbabwe, which all were embroiled in civil wars or political instability when China engaged and which have today become among the most important sources of Chinese imports in primary commodities as well as Beijing's key diplomatic partners in Sub-Saharan Africa.

From a moral perspective, both Africa and China have long argued that economics must supersede politics, as it could be seen as morally wrong to deny much needed investments and its attendant benefits, including employment and better standards of living, to needy populations. Being ruled by leaders falling short of western democratic standards should not be upheld as a formal justification to deny investments to economies in need of external stimuli.

\subsection{Towards more symmetrical and less conditional Africa - Europe relations}

The turn of the Millennium, beginning from the year 2000, presents a good opportunity for Europe, now represented by the canopy European Union (EU), and Africa, most often represented by the canopy African Union (AU), to re-evaluate their investment relationship (Brown 2002). I argue and demonstrate 
here that if the EU or Europe as a whole (since not all European countries are EU members and since some EU members like Britain are threatening to exit or already on their way out with referenda such as what the UK did in June 2016 to trigger a Brexit) doesn't want to put itself in danger of being over-taken by others, especially the emerging economies from Asia, it needs to re-invent itself along three parameters.

i. Let politics be politics and investment be investment

As outlined above, earlier in Table 1 showing the general investment trends of major countries in the EU, Europe has tended to impose socio-economic and socio-political conditionalities on African recipients of its foreign investment. These conditionalities have often led to unstable political systems, inefficient economies and social vices such as corruption. Indeed, it can be argued that the turmoil we see in many African countries is not because Africans are incapable of ruling themselves but that it is precisely because of these externally imposed SAPs that have made it impossible to govern certain countries on the African continent whether or not one were an African. In fact, it has sometimes led to defiance against Europe in the form of military coups and uprisings against imperialism, leading to dictatorship regimes, which then have to find ways of staying in power by either looking to alternative sources of investment and economic development or simply just suppressing their citizens over many decades. This situation then creates the need for further European intervention, this time, in the form of "development aid" and humanitarian assistance by both European government and non-governmental organizations (NGOs). This vicious cycle cannot continue forever. The way forward is for Europe to mitigate or even completely abandon its unrealistic conditionalities of engagement and rather engage purely in investment with Africa. Politics should be kept separate from business as much as possible. Let politics be politics and investment be investment! Notice that, linguistically, the term 'conditionalities' is different from the term 'conditions' (of engagement). Conditionalities are one-sided, asymmetrical constraints imposed by one party in a dialogue between two or more parties while conditions are negotiated, more or less, symmetrical rules of engagement between two or more parties. So the EU can still have negotiated rules of engagement rather than imposing widespread neo-colonial and super-power socio-economic and socio-political conditionalities on their African investment partners.

\section{ii. Trade and investment, not aid}

We have seen that Europe tends to focus more on development aid than on investment when it comes to its economic engagement with Africa. ${ }^{10}$ This, as mentioned earlier, is a major European distinction. But this distinctive engagement is unsustainable. It creates many economic disconnects, leading to the dependence by many African economies on European governmental and NGO aid. In the $21^{\text {st }}$ Century to remain a serious economic partner in Africa and take advantage of Africa's rich natural resources, the EU must reverse this equation, focusing more on purely trade and investment, which would hopefully lessen the need for development aid by the EU and individual European governments and their NGOs.

\footnotetext{
10 An anonymous reviewer has raised the issue of why European investment might be low: "What are ways of making the region more convergent and possible for forecasting, as this is the base for investing. No investor will be interested in high risks". In other words, according to this reviewer given the high risks in Africa because Africa might not be 'convergent' for possible forecasting, Europeans may not be as enthusiastic to invest, and instead prefer to get involved in development aid. Well, that is one of the crucial points of my argumentation in this paper: China has chosen to take more risks than Europe and in the process it has increased its investments - and profits thereof - far more than Europe. Risk taking is at the very heart of business ventures! As to how one might make Africa more 'convergent' for forecasting, that might be another topic for study and it is beyond the scope of my current paper.
} 


\section{iii. The role of the African diaspora}

A third way in which the EU can reinvent itself and remain as a dominant investment partner in Africa is to retool its economic actors in its relations with Africa. There now exists a large number of Europeans of African descent. Many of these naturalized Europeans came to Europe first as controlled migrant including professionals and people uniting with families while some came as refugees and illegal immigrants Indeed, putting aside the history of trans-Atlantic slavery, there are more professionals and other peoples of African descent in Europe than anywhere in the world. The African Diaspora appears to be more vibrant and more salient in many European countries than anywhere in the world as most professionals have had to move to Europe as economic refugees, as mentioned above. This can serve as a comparative advantage that the EU has over many parts of the world, if well managed. These Europeans of African descent can take the lead and serve as efficient actors to re-engineer FDI in Africa to enable the EU reinvent itself in Africa in the face of massive competition from more and more efficient emerging economies.

\section{CONCLUSIONS}

I have in this paper discussed differing approaches to the way Europe, led by the EU, and China have engaged Africa, at least, since the turn of the Millennium. Whereas it is often argued that what China is doing in Africa is not different from what Europe has done and is doing in terms of the pursuit of selfinterest, I argue that there are clearly different strategies used by these two investment partners of Africa. In the Africa - China - Europe constellation, European actors tend to impose more conditionalities on investments in Africa than what China does in Africa.

My arguments have been supported by various statistics and policy statements, such as the Forum for Africa - China Cooperation (FOCAC) delcarations,

Chinese strategies of developing a discourse - and possibly a practice - of non-interference and striving for symmetric win-win conditions of engagements in Africa seem to be working better than European strategies of arm-twisting, heavily conditional investments.

\section{ACKNOWLEDGEMENT}

I thank Professor Gerd Kaminsky, President of the Austrian Institute for China and Southeast Asia Research for asking me to present a plenary paper at his conference on Chinese Strategies in Politics, Foreign Policy, Security Policy, Economy and Law in October 2018. I also thank Professor Karl Aigner of the Policy Cross-Over Consultancy Group in Vienna and Flavia Inzikuru of Lansky and Partners Law Firm in Vienna for inviting me to give presentations on the differences between China and Europe in Africa during the High Level Summit on Africa and EU in Vienna in December 2018. All these fora helped shape the ideas and arguments stated in this paper.

\section{REFERENCES}

Amra, R. (2011). "Suleimaniye Minarets on the Midrand: Turkey's Economic Incipience in Africa." Perspectives on Emerging Powers in Africa. from https://www.pambazuka.org/images/Emerging\%20Powers\%20newsletter\%20May\%202011/Issue\%209\%2 0May\%202011.pdf.

Berger, B., \& Wissenbach, U. (2007). EU-China-Africa trilateral development cooperation: common challenges and new directions. Retrieved from www.diegdi.de/CMSHomepage/openwebcms3.nsf/(ynDK_contentByKey)/ADMR7BRFHU/USDFILE/ 
Bodomo, A. (2019). Africa - China - Europe Relations: Conditions and Conditionalities. In Chinese Strategies, edited by Kaminski, Gerd, 119-140. Vienna, Austria: OEGCF.

Bodomo, A. (2018). Is China colonizing Africa?. In Global Economic Governance and Human Development, edited by Raudino, S. \& Poletti, A., 120-132. Abingdon: Routledge.

Bodomo, A. (2017). The Globalization of Foreign Investment in Africa: The Role of Europe, China and India.Bingley: Emerald Publishing.

Bodomo, A. (2016). The rise of Chinese soft power in Africa. China Policy Institute Blog, the University of Nottingham. Retrieved from http:// blogs.nottingham.ac.uk/ chinapolicyinstitute/ 2016/ 03/ 24/ therising- of- chinese- soft- power- in- africa/)

Bodomo, A. (2015). African soft power in China. African East-Asian Affairs, 2, 76-97.

Bodomo, A. (2010). The African trading community in Guangzhou: an emerging bridge for Africa-China relations. China Quarterly, 203, 693-707.

Bodomo, A. (2009). Africa-China relations: symmetry, soft power, and South Africa. The China Review: An Interdisciplinary Journal on Greater China, 9(2), 169-178.

Broadman, G., Isik, G., Plaza, S., Ye, X., \& Yoshino, Y. (2007). Africa Silk Road. Washington, DC: World Bank.

Broadman, H. (2008). China and India go into Africa: new deals in the developing world. Foreign Affairs, 87(2), 95 109.

Brown, William. (2002). The European Union and Africa: The restructuring of North-South relations. New York: I. B. Tauris.

Chand, M. (2011). A two-way street: India brands its Africa diplomacy. Perspectives on emerging powers in Africa. Retrieved from www.pambazuka.org/i mages/ Emerging\%20Powers\%20newsletter\%20May\%202011/ Issue $\% 209 \% 20$ May\%20 2011.pdf

Commission of the European Communities. (2008). The EU, Africa and China: Towards trilateral dialogue and cooperation. European Commission.

Games, D. (2005). Chinese the new economic imperialists in Africa. Business Day, February.

Graham, J., \& B. Spaulding. (no date). Understanding Foreign Direct Investment. Citibank International Business Portal. (http://www.going-global.com/articles/understanding_foreign_direct_investment.htm)

Hilsum, L. (2006). China's offer to Africa: pure capitalism. New Statesman. Retrieved from https://www.newstatesman.com/node/164688

Li, A. (2016). Technical assistance and technology transfer between China and Africa from TAZARA to Huawei. Manuscript. Peking University.

Monson, J. (2009). Africa's Freedom Railway: How a Chinese Development Project Changed Lives and Livelihoods in Tanzania. Bloomington: Indiana University Press.

Moyo, D. (2010). How the West Was Lost: Fifty Years of Economic Folly - And the Stark Choices that Lie Abead. New York: Farrar, Straus and Giroux.

Moyo, D. (2009). Dead Aid: Why Aid Is Not Working and How There is Another Way for Africa. New York: Farrar, Straus and Giroux.

Raudino, S. (2016). Development Aid and Sustainable Economic Growth in Africa: The Limits of Western and Chinese Engagements, London: Palgrave MacMillan.

Rodney, W. (1972). How Europe Underdeveloped Africa. London: Bogle L'Ouverture Publications.

Sanusi, L. (2013). Africa must get real about Chinese ties. Financial Times. Retrieved from www.ft.com/ cms/ s/ 0/ 562692b0- 898c- 11e2- ad3f- 00144feabdc0. html\#axzz476hHV2XM)

Sautman, B., \& Yan, H. (2007). Wind from the East: China and Africa's Development. In NGOs Conference on China in Africa, Shanghai.

Smith, S. (2010). How France Maintains Its Grip on Africa." BBC Focus on Africa Magazine. Retrieved from http://news.bbc.co.uk/2/hi/africa/8639874.stm

UNCTAD. (2017). World Investment Report 2017: Investment and the Digital Economy. United Nations Publication.

UNCTAD. (2010). World Investment Report 2010: Investment and the Digital Economy. United Nations Publication.

Vicky, A. (2011). Turkey moves into Africa. Le Monde Diplomatique. Retrieved from http://mondediplo.com/2011/05/08turkey 
Wissenbach, U. (2009). The EU's response to China's Africa safari: can triangulation match needs?. European Journal of Development Research, 21(4), $662-674$.

Wissenbach, U. (2008). The Renaissance or the End of Geopolitics? Towards Trilateral Cooperation in Africa." Shanghai:

Institute of International Studies. Retrieved
www.siis.org.cn/Sh_Yj_Cms/Mgz/200802/2008928113740SY6K.PDF) 